\title{
PERBANDINGAN HASIL BELAJAR MULTIMEDIA INTERAKTIF MODEL TUTORIAL DENGAN MEDIA HANDOUT PADA KOMPETENSI GAMBAR TEKNIK
}

\author{
Rollyka Doreng ${ }^{1}$, Ono Wiharna², Mumu Komaro ${ }^{3}$ \\ Departemen Pendidikan Teknik Mesin \\ Universitas Pendidikan Indonesia \\ Jl. Dr. Setiabudhi No. 207 Bandung 40154 \\ rollykadoreng@gmail.com
}

\begin{abstract}
ABSTRAK
Tujuan dari penelitian ini diharapkan dapat: mengetahui gambaran hasil belajar siswa dengan menggunakan media handout dan media interaktif model tutorial pada mata pelajaran gambar teknik; dan mengetahui perbedaan perbandingan peningkatan hasil belajar pada mata pelajaran gambar teknik siswa yang menggunakan media handout dan media interaktif model tutorial. Penelitian ini menggunakan metode quasi eksperimen dengan desain nonequivalent control group design yang dilaksankan pada semester genap tahun pelajaran 2015/2016 dengan mengambil sampel 2 kelas yaitu TKR 1 dan TKR 2 di SMK Negeri 8 Bandung. Instrumen penelitian yang digunakan adalah Instrumen tes (soal pre-test dan post-test) dan Instrumen non tes (lembar judgment media dan lembar judgment materi). Hasil penelitian menunjukan bahwa penggunaan multimedia interaktif model tutorial membantu meningkatkan kemampuan siswa menjadi lebih baik dibandingkan dengan media handout dengan rata-rata prestasi siswa yang belajar menggunakan media handout mendapatkan nilai $N$ gain sebesar 0,51 (sedang). Rata-rata prestasi siswa yang belajar menggunakan multimedia interaktif model tutorial mendapat nilai $\mathrm{N}$-gain sebesar 0,54 (sedang). Kesimpulan dari penelitian ini adalah multimedia interaktif dapat meningkatkan hasil belajar siswa lebih baik dari pada media handout.
\end{abstract}

Kata kunci: media, pembelajaran, handout, multimedia interaktif, tutorial.

\section{LATAR BELAKANG}

Perkembangan pengetahuan dan teknologi membawa pengaruh terhadap perkembangan pendidikan. Pendidikan di Indonesia selalu berubah setiap 5 tahun sekali dengan perubahan kurikulum. Pembaharuan di bidang pendidikan ini diharapkan dapat membuat perubahan dari aspek sikap dan perilaku dari nilai norma dan pengetahuan pada individu dan masyarakat. Strategi, model, metode, dan teknik pembelajaran dibutuhkan untuk mengimbangi pembaharuan dalam bidang pendidikan. Oleh karena itu, guru sebagai pendidik dipacu untuk harus memiliki kekreatifan dalam mengembangkan strategi, model, metode dan teknik pembelajaran tersebut (Anitah, 2010).

Proses pembelajaran pada hakekatnya merupakan proses komunikasi. Proses penyampaian pesan dari sumber pesan melalui media atau saluran tertentu ke penerima pesan. Proses belajar mengajar mengkomunikasikan pesan dari guru kepada siswa, pesan tersebut merupakan materi pelajaran. Proses komunikasi sering tidak berjalan dengan efektif karena

\footnotetext{
${ }^{1}$ Mahasiswa Departemen Pendidikan Teknik Mesin FPTK UPI

2 Dosen Departemen Pendidikan Teknik Mesin FPTK UPI

${ }^{3}$ Dosen Departemen Pendidikan Teknik Mesin FPTK UPI
} 
adanya faktor penghambat. Dalam proses pembelajaran faktor penghambatnya merupakan pesan pembelajaran atau materi yang sulit dipahami oleh siswa sebagai penerima pesan (Binanto, 2010).

Pembelajaran yang telah dilakukan seharusnya membuat siswa memiliki suatu perubahan kemampuan, dalam perakteknya didalam kelas seharusnya siswa mendapati nilai yang baik. Belajar tuntas merukapan pembelajaran yang dilakukan secara sistematis dan terstruktur. Bertujuan untuk mengadaptasi pembelajaran pada siswa kelompok besar, membantu mengatasi perbedaan yang terdapat pada siswa dan berguna untuk menciptakan kecepatan belajar. Belajar tuntas diharapkan mampu mengatasi kelelahan yang melekat pada pembelajaran klasikal (Djamarah dan Zain, 2006).

Berdasarkan pengalaman melaksanakan Program Pelatihan Lapangan (PPL) di SMKN 8 Bandung diperoleh data bahwa siswa ketika mengikuti kegiatan Ujian Akhir Semester (UAS) pada mata pelajaran gambar teknik cukup rendah. Rendahnya hasil belajar siswa disebabkan oleh: kurangnya daya tangkap siswa mengenai materi yang diberikan karena penyampaian yang terlalu cepat, keterbatasan waktu belajar dikelas, penggunaan media belajar handout yang digunakan oleh guru tidak dapat langsung dimengerti. Siswa SMK yang cenderung sulit menerima materi yang diberikan karena kurang meminati pembelajarannya berpengaruh terhadap penguasaan dan pemahaman materi (Sanjaya, 2010). Tugas terstruktur yang diberikan berdasarkan materipun menjadi terasa sulit untuk dikerjakan dan membuat hasil belajarpun tidak maksimal. Berdasarkan identifikasi masalah tersebut tujuan kompetensi dasar dan KKM yang telah ditetapkan tidak tercapai.

Salah satu komponen yang mendukung dalam pembelajaran yaitu pemilihan media pembelajaran yang tepat. Media pembelajaran ini tidak hanya harus terkini dan inovatif, akan tetapi media tersebut harus efektif dan efesien dalam mata pelajaran tersebut. Media pembelajaran yang digunakan sangat bergantung kepada tujuan pembelajaran (Suheri, 2006). Pengoptimalan pencapaian tujuan pembelajaran pada materi gambar teknik perlu penggunaannya sebuah media pembelajaran yang memungkinkan siswa untuk belajar mandiri ketika sudah tidak dalam jam belajar. Media interaktif model tutorial diharapkan dapat menunjang penguasaan konsep, materi ini yang divisualisasikan dalam bentuk video tutorial lebih mudah dimengerti dan menarik perhatian siswa sehingga siswa tidak bosan.

Media interaktif model tutorial dapat merangsang siswa belajar mandiri dan diakhiri dengan mengerjakan soal latihan yang hasilnya dapat diketahui oleh siswa dan tugas terstruktur. Materi yang sulit dipahami dapat dipelajari secara mandiri dan dipelajari lebih 
mendalam. Media interaktif tutorial dalam penggunaannya dapat meringankan peran guru dalam kelas dan memungkinkan mengganti peranan guru dalam proses belajar mengajar. Sama seperti pembelajaran dinegeri maju yang peran guru sudah tergantikan dalam beberapa mata pelajaran oleh media, akan tetapi tidak mengurangi nilai pengetahuan dan hasil belajar siswa, dan tidak mengurangi nilai guru sebagai fasilitator. Model ini dipilih karena dapat merangsang belajar siswa secara mandiri. Model pembelajaran seperti ini belum dapat dilakukan di Indonesia sebab masih terbenturnya sarana dan hanya bisa dilakukan dibeberapa sekolah yang mempunyai sarana yang memadai.

Tujuan penelitian ini yaitu untuk mengetahui gambaran hasil belajar siswa dengan menggunakan media handout dan media interaktif model tutorial pada mata pelajaran gambar teknik; pada mata pelajaran gambar teknik; dan untuk mengetahui perbedaan peningkatan hasil belajar pada mata pelajaran gambar teknik siswa yang menggunakan media handout dan media interaktif model tutorial.

Para ahli psikologi pendidikan telah banyak mengemukakan pengertian dari belajar. Secara psikologis pengertian belajar merupakan proses perubahan tingkah laku akibat inetraksi dengan lingkungannya. Belajar adalah suatu proses usaha yang dilakukan seseorang untuk memperoleh suatu perubahan tingkah laku yang baru secara keseluruhan, sebagai hasil pengalamannya sendiri dalam interaksi lingkungannya (Uno, 2010).

Media merupakan bentuk jamak dari perantara (medium), merupakan sarana komunikasi (Sharon, 2011). Media merupakan prantara yang membawa informasi dari seorang atau sebuah sumber kepada penerima informasi tersebut. Fungsi utama media pembelajaran adalah sebagai alat bantu mengajar yang turut memengaruhi iklim, kondisi dan lingkungan belajar yang ditata dan diciptakan oleh guru (Arsyad, 2009). Adanya alat-alat modern seperti slide, opaque, film dan sebagainya yang lebih memuaskan dan menyenangkan untuk mencapai tujuan mengajar.

Belajar merupakan suatu proses usaha diri dengan ditandai oleh adanya perubahan tingkah laku berdasarkan pengalaman dan pengetahuan yang didapat berdasarkan interaksi dengan lingkungan. Keberlangsungan kegiatan proses belajar mengajar dikatakan baik jika terdapat interaksi antara guru dan siswa. Hasil belajar dipengaruhi oleh beberapa faktor seperti faktor fisiologis dan psikologis yang mempengaruhi siswa dan faktor sosial, budaya, lingkungan, dan spiritual. Faktor-faktor yang mempengaruhi hasil belajar ini dapat dimanipulasi dengan bantuan multimedia pembelajaran (Slameto, 2013). Media membuat pengalaman baru untuk siswa saat melakukan proses belajar. Media yang dipilih untuk 
melakukan penelitian ini adalah multimedia interaktif model tutorial, media ini dapat membantu pengguna dalam memahami materi dan materi langsung dapat dipraktikan. Media interaktif model tutorial juga dapat mengulangi materi yang diberikan karena memiliki fungsi repeat dalam penggunaannya.

\section{METODE PENELITIAN}

Penelitian ini menggunakan metode penelitian quasi eksperimental dengan desain Nonequivalent Control Group Design. Metode penelitian quasi eksperimental yaitu pengontrolan pada variable-variabel tidak secara penuh atau ketat, tetapi disesuaikan dengan kondisi yang ada. Pemilihan metode ini berdasarkan pada ketetapan tujuan penelitian yang sejalan dengan metode penelitian ini. Sampel penelitian adalah siswa kelas yaitu TKR 1 dan TKR 2 di SMK Negeri 8 Bandung. Instrumen penelitian yang digunakan adalah tes (soal pretest dan post-test) dan instrumen non tes (lembar judgment media dan lembar judgment materi).

\section{HASIL PENELITIAN}

Hasil data yang dihasilkan melalui pre-test, post-test dan $N$-Gain adalah sebagai berikut: pretest kelas kontrol rata-rata 67,9, pretest kelas eksperimen rata-rata 62,4. Posttest kelas kontrol rata-rata 84,4 dan posttest kelas eksperimen rata-rata 82,4. $\mathrm{N}$-gain kelas kontrol adalah 0,51 dan $N$-gain kelas eksperimen yaitu 0,54.

\section{PEMBAHASAN}

Penelitian pada kelas yang menggunakan media handout, sebelum dilakukan proses belajar dilakukan pre-test. Proses kegiatan belajar mengajar berlangsung terlihat bahwa siswa tidak terlalu antusias dilihat dari saat pemberian materi gambar siswa hanya merespon seperlunya untuk menjawab pertanyaan dan latihan menggambar (Arifin, 2012). Setelah itu siswa diminta untuk mengerjakan soal post-test. Hasilnya diperoleh sebagai berikut: rata-rata prestasi siswa yang belajar menggunakan media handout pada mata pelajaran gambar teknik mendapatkan nilai pada saat pre-test sebesar 67,9 nilai ini berada pada kategori belum terampil. Setelah dilakukan treatmen dan dilakukan post-test nilai rata-rata siswa menjadi 84,4. Nilai ini berada pada kategori baik dengan nilai $N$-Gain sebesar 0,51 yang berada pada posisi sedang. Hasil rata-rata post-test dan $N$-Gain media handout masih mampu meningkatkan hasil belajar siswa dan dinilai baik. 
Peneliti pada kelas yang menggunakan multimedia interaktif model tutorial, sebelum dilakukan proses belajar, dilakukan pre-test. Proses kegiatan belajar mengajar berlangsung terlihat bahwa siswa antusias sebab dari saat pemberian materi gambar teknik siswa sudah bertanya dan tidak sabar dengan aplikasi flash yang siap dioperasikan oleh mereka. Guru berperan sebagai fasilitator untuk membantu siswa dalam mengoperasikan aplikasi (Nandi, 2006). Guru juga mengingatkan siswa untuk berpindah pada sesi selanjutnya untuk mengefesiensikan waktu. Siswa sangat terbantu oleh video tutorial dan animasi pengerjaan pada proses latihan menggambar (Rusman, 2012). Siswa diminta untuk mengerjakan soal post-test setelah proses pembelajaran berakhir. Hasilnya sebagai berikut: rata-rata prestasi siswa yang belajar menggunakan multimedia interaktif model tutorial pada mata pelajaran gambar teknik mendapat nilai pada pre-test sebesar 62,4. Nilai ini masuk kategori belum terampil. Setelah dilakukan treatmen dan dilakukan post-test nilai rata-rata siswa menjadi 82,4 . Nilai ini masuk kategori baik dengan nilai $N$-Gain sebesar 0,54 yang berada pada posisi sedang. Hasil rata-rata post-test dan $\mathrm{N}$-Gain multimedia interaktif model tutorial mampu meningkatkan hasil belajar siswa dan dinilai baik.

Peningkatan hasil belajar terlihat setelah siswa melakukan perlakuan. Kedua media terbukti meningkatkan hasil belajar akan terlihat pada hasil post-test kedua kelas memiliki hasil rata-rata yang meningkat (Royada, 2008). Nilai $N$-Gain yang dapat dilihat setelah pengolahan data, dapat dilihat bahwa multimedia interaktif model tutorial lebih baik dibandingkat dengan media handout yang sering digunakan dalam pembelajaran dikelas (Anitah, 2010). Nilai rata-rata $\mathrm{N}$-Gain multimedia interaktif model tutorial sebesar 0,54. Sedangkan media handout memiliki nilai rata-rata $N$-Gain sebesar 0,51 meskipun keduanya berada pada katagori sedang.

\section{KESIMPULAN}

Kesimpulan penelitian ini, sebagai berikut: rata-rata prestasi siswa yang belajar menggunakan media handout dan multimedia interaktif model tutorial mendapatkan nilai yang berada pada kategori baik. Peningkatan hasil belajar siswa yang menggunakan multimedia interaktif model tutorial lebih tinggi dari pada hasil belajar siswa yang menggunakan media handout. Hal ini terlihat perbedaan hasil dari nilai N-gain yang lebih besar, walaupun keduanya berada pada katagori sedang. 


\section{DAFTAR PUSTAKA}

Anitah, S. (2010). Media Pembelajaran. Surakarta: Yuma Pustaka.

Arifin, Z. (2012). Evaluasi Pembelajaran. Bandung: Remaja Rosdakarya.

Arsyad, A. (2007). Media Pembelajaran. Jakarta: Raja Grafindo Persada.

Binanto. (2010). Multimedia Digital-Dasar Teori dan Pengembangannya. Yogyakarta: Andi.

Djamarah, S. B. dan Zain, A. (2006). Strategi Belajar Mengajar. Jakarta: Rineka Cipta.

Nandi. (2006). Penggunaan Multimedia Interaktif Dalam Pembelajaran Geografi di Persekolahan. Jurnal GEA Jurusan Pendidikan Geografi.

Royada, D. (2008). Media Pembelajaran. Ciputat: Gaung Persada.

Rusman. (2012). Model-Model Pembelajaran Mengembangkan Profesionalisme Guru. Jakarta: Raja Grafindo Persada.

Sanjaya, W. (2010). Perencanaan dan Desain Sistem Pembelajaran. Jakarta: Kencana Perdana Grup.

Sharon. (2011). Instructional Technology \& Media for Learning. Jakarta: Kencana Prenada Grup.

Slameto. (2013). Belajar dan Faktor-Faktor yang Mempengaruhinya. Jakarta: Rineka Cipta.

Suheri. (2006). Multimedia Pembelajaran. Bandung: Citraindo.

Uno, H.B. (2010). Orientasi Baru dalam Psikologi Pembelajaran. Jakarta: Bumi Aksara. 